\title{
Development of Production-Based MPDW Teaching Materials to Increase Students' Entrepreneurship Competency in Office Administration Education, Faculty of Economics Universitas Negeri Medan
}

\author{
Rotua Sahat Pardamean Simanullang ${ }^{1}$, Ratna Manullang ${ }^{2}$, Gartima Sitanggang ${ }^{3}$ \\ \{rotuaspsimanullang@gmail.com ${ }^{1 *}$, ratnamanullang@,rocketmail.com ${ }^{2}$, \\ artimasitanggang@yahoo.co.id $\left.{ }^{3}\right\}$ \\ 1,2,3Fakultas Ekonomi Universitas Negeri Medan, Indonesia \\ *rotuaspsimanullang@gmail.com
}

\begin{abstract}
The development of the tourism industry and the increase in the desire to travel the community provides opportunities for students to become travel industry actors. Answering these needs the Office Administration Education Study Program formed a Subjects of Travel Management and Tourism (MPDW), to equip students with entrepreneurial skills in the travel business. To support the ongoing learning process, it requires the availability of comprehensive MPDW teaching materials, which are arranged systematically to be used in learning to produce competent students who are able to produce travel service products that are ready to be entered into the tourism industry market. The purpose of this research is to develop comprehensive production-based MPDW teaching materials in order to improve the entrepreneurial competency of office administration education students in travel business. This research uses a research and development approach (R\&D) by adopting a model developed by Dick \& Carey. The research began with an analysis of the need for MPDW textbooks, establishing learning experiences and general goals. Followed by the design of teaching materials that will be developed beginning with the Forum Group Discussion with the lecturer team, then a draft of teaching materials is prepared. The next step is validating tourism and business travel experts, tourism marketing experts and book design experts. After getting the eligibility from experts, it was followed one by one experiment with 3 students, smallgroup trials with 20 students and large-group trials with 38 students. From the tests conducted, it was found that: 1) MPDW teaching materials based on production are interesting; 2) this teaching material facilitates students to dare to design a travel bureau business (travel); 3) able to design attractive travel packages according to market requirements; 4) MPDW teaching materials developed facilitate students to dare to market the developed travel packages and 5) facilitate students to be able to become tour leaders and tour guides for the resulting travel packages.
\end{abstract}

Keywords: Production Based Learning, Teaching Materials, Development Research.

\section{Introduction}

Tourism has become a very promising business nowadays. Millions of people spend big money to satisfy or make themselves happy in order to spend leisure time, travel, treatment, religious travel and so on. The CEO of the World Travel \& Tourism Council (WWTC) said 
travel and tourism were important contributors to the Indonesian economy which accounted for more than 55 percent of Indonesia's service sector exports. The development of the tourism industry is also an opportunity for job creation for job seekers. According to WWTC data, the travel and tourism sector creates 2.4 million new jobs in Indonesia and contributed 6.2 percent to Indonesia's gross domestic product.

The development of the tourism industry will require graduates who are ready to enter the tourism industry market. Responding to the market's need to produce graduates of Office Administration Education Study Program who are competent to become entrepreneurs in the tourism industry, relevant subjects are needed. The Subjects of Travel Management and Tourism (MPDW) is one of the supporting subjects, in addition to other subjects. Through MPDW learning activities, students are expected to master entrepreneurial competencies in the tourism sector and be interested in becoming businessman in this sector that can create job opportunities in this labor-intensive sector.

According to BPS data from February 2017 to February 2018, the unemployment rate for university graduates increased by $1.13 \%$ from $5.18 \%$ to $6.31 \%$. Likewise for diploma graduates there was an increase of $1.04 \%$ from $6,88 \%$ to $7.92 \%$. The amount of unemployment with a university level is due to the orientation of scholar graduates who tend to be picky about jobs. The desire of students to become an entrepreneur is still low. While the current conditions the opportunity to become entrepreneurs is wide open with the development of the media and the development of the creative economy, especially the tourism sector.

The low desire of graduates to become entrepreneurs is due to their low entrepreneurial competence. Graduates are not able to see business opportunities that exist with the rapid tourism industry nowadays. For this reason, it is deemed necessary to improve students' entrepreneurial competencies, especially in tourism and travel. The initial survey conducted for students of the Office Administration Study Program of 2016 generation in May 2019 obtained data that the low interest of students for entrepreneurship, only around $42.5 \%$ were interested in becoming entrepreneurs out of 110 students. The low interest in entrepreneurship can be caused by several factors including, first, lecture material on the subject does not touch the technical issue to go right into the business world, second, the lack of students' understanding of the basic concepts of the tourism industry, especially in the travel business. Third, the lack of teaching materials or books that discuss about travel management and tourism business materials that focus on entrepreneurial practices, and Fourth, the lack of a successful entrepreneur profile in the travel industry exposed by the media. This competency improvement effort must be supported by lecturers and appropriate teaching materials. The teaching materials needed are teaching materials that emphasize the ability of students to produce products, both in the form of goods and services needed in the tourism industry. Students are educated with learning experience in contextual situations following the work flow in the tourism industry starting from business planning, marketing, implementation, and evaluation of the products produced. For this reason, it is necessary to develop teaching materials for MPDW subjects with a Model Production Based Learning so that students can be motivated and practice in producing travel service products that are in accordance with market demands.

Based on the explanation above, this research becomes very important by seeing the increasing number of graduates, the development of the travel industry, the rapid desire of people to travel, and the increasingly developing information technology and social media. Such conditions are expected to foster self-confidence and motivate students to become entrepreneurs who enter the tourism business, especially travel, so as to reduce unemployment for college graduates and create new jobs in the community. 
The development of the tourism industry including the travel industry can increase job opportunities for many people, including for college graduates who choose to become entrepreneurs. An increase in job opportunities in the community both direct and indirect [1]. Direct job opportunities are those directly involved in the tourism sector, while those who are indirect are suppliers for all needs. For this reason, the preparation of college graduates to enter the workforce is very much determined by the exploration of their abilities during the teaching and learning process on campus.

The implementation of the 2018 KKNI now allows students to explore all of their abilities and market needs oriented. Students can explore, assess, interpret, synthesize, and information to produce various forms of learning outcomes. KKNI is a set of documents that combines the scientific ontology of study programs (deductive mindset) with business and industry competencies (inductive mindset) [2]. The focus of KKNI development lies in the attitudes, knowledge and skills of students in learning experiences in the form of instructional effects and natural effects. The product-based learning model is highly expected in the implementation of KKNI, which in the learning process students are active and collaborative in groups to produce a joint product that is ready to be entered into the industrial world in society. By giving assignments to produce products in groups, students will be trained to design products, carry out production, evaluate the products produced, and plan marketing, besides that students must also work together in completing assignments.

To support the ability to produce the product as a whole, it has implications for what each student must learn, how to teach it, and what teaching materials are needed to support the achievement of these competencies. MPDW subjects are subjects that are building the concepts and skills of students to be able to design travel services and tourist attractions that will be presented during the trip. In accordance with the characteristics of practical materials, learning by lecturing and training methods is not appropriate, production-based learning is one of the best alternatives. Production-based learning model is a process of education and training that is integrated into the production process, where students are given learning experience in contextual situations following the industrial workflow starting from planning based on order [3]. The main objective of this learning model is that graduates can play a role in increasing the empowerment of the region's potential to spur economic growth.

The learning activities carried out so far for MPDW subjects have entered into participatory learning with the project learning model. But student assignments are still not directed to be able to enter the world of the travel industry. The services designed by students are still only oriented to the internal needs of students' own travel practices. Students have designed a travel package complete with tourist objects visited with tourist attractions displayed, but only equipped with one type of travel cost calculation that is tailored to the needs of the student. Students have not arranged travel services according to the needs of the industry that are tailored to the desires of tourists who will travel. Students have not designed a travel service with various budget combinations that are tailored to the types of tourists visiting. Students also have not entered services designed into the market either through networks or outside the network. They have not yet planned the marketing of the service products they produce.

Learning activities require teaching materials that are designed in the form of teaching materials. Based on constructivist learning theory, learning is an active activity. Learning must enable students to learn actively at their own pace and accommodate learning by doing. Based on the characteristics of lecture material that is full of practice, production-based teaching materials become very important, MPDW teaching materials based on production that are designed according to the needs of practical subjects where teaching materials will include: 
material covering the basic concepts of tourism and travel consisting of basic concepts of tourism, travel history and management, tourist motivation, tourism systems, tourism resources, forms of travel, tourism industry, relations and cooperation, travel route design, preparation of an travel itinerary, calculation of travel costs, product marketing, travel preparation, tourism area development, and ecotourism [4].

The results of a meeting with the Head of Tourism Object Management and Tourism Marketing Sub-Division of Dairi District stated that the tourism sector requires very many entrepreneurs engaged in tourism and requires direct and indirect labor. However, due to the lack of willingness of scholars to become entrepreneurs, what has happened to the tourism sector has not been able to become a leading sector in North Sumatra Province in general and especially in Dairi District, although it has the main resources and supporting in tourism with beautiful natural resources, the culture of the people and the uniqueness of life and the products produced.

Furthermore, the dialogue conducted during the student tourism study in Karo District, Head of Tourism Marketing in Tanah Karo conveyed the lack of entrepreneurs willing to invest in the tourism sector making attractions presented to tourists tend to be monotonous, innovation in attractions and natural tourism objects and artificial very limited in number. This results in the desire of tourists to repeat the visit to be a small chance. If there are many entrepreneurs who are willing to innovate in attractions, tourism objects and local, national and international cuisine, it will certainly bring even more tourists.

In line with the discussion with the Head of Mangrove Coast Management Sei Nagalawan Perbaungan, said that it was difficult to invite scholar graduates to become entrepreneurs in the tourism business. Many scholars have pinned their hopes to just being civil servants or working in companies or going abroad as workers. Very few scholars are immediately ready to jump into an entrepreneur, including in tourism [5]. It is hoped that the campus can prepare many scholars who are motivated to become job creators in the tourism sector with a lot of links.

The above view is supported by the results of the pre-survey conducted to see how much the motivation of organizational students from 102 students of the Office Administration Education Study Program at Universitas Negeri Medan found that only $42.53 \%$ of students had the motivation to become entrepreneurs. To answer all of these problems, students should be prepared to become an entrepreneur according to the profile of the graduate study program that has been established, namely in addition to being a teacher and secretary, also becoming an entrepreneur in tourism. To support that, teaching materials are needed that can equip students in the form of cognitive abilities with the concept of tourism and travel, and must also be given space to practice designing travel service products that are ready to be launched to the community. So students besides being rich in concept skills also have the courage to enter the industrial world to become one of the actors. For this reason, there is a need for standardization: learning indicators, content of teaching materials, learning models, evaluation instruments as outlined in the production-based MPDW teaching materials so that each student of the Office Administration Study Program of Universitas Negeri Medan has competencies in accordance with the needs of the industrial world.

Production-based MPDW teaching materials are developed based on learning design theory. There are four conditions for the fulfillment of a good teaching material, namely (1). The scope of the material or content is in accordance with the curriculum, (2). The presentation of the material meets the principles of learning, (3). The language and good readability, (4). The format of the book with interesting graphics [4]. Teaching material as learning content is written by instructors that contain material that aims to facilitate the 
learning process of students. Teaching material is a good criterion if the teaching material is written in good language and is easy to understand, is presented in an interesting manner accompanied by pictures and explanations, the contents of the book also illustrate something based on the author's idea [6]. Teaching materials developed based on production-based learning have the characteristics of solving problems in the real world [7]. The core components in production-based learning include: 1) communicative content description, 2) using examples, illustrations or analogies, 3) using exercises, tests and corrective feedback, 4) selection of relevant media, 5) relevance and consistency between exercises or test and learning objectives materials and 6) interactive activities [5,8].

\section{Research Methods}

This research uses a research and development approach (R\&D). The development model that will be used is the Dick \& Carey Model. The method used is descriptive exploratory method to identify various symptoms and root problems that occur in MPDW learning and the design of the development of MPDW Teaching Materials. The research subjects in this research were one expert in the contents of travel tourism materials, a tourism marketing expert, a book design expert and students of the Office Administration Education Study Program of 2016 generation.

The location of this research took place in the Office Administration Education Study Program, Faculty of Economics, Universitas Negeri Medan. The instrument used was a questionnaire and interview guidelines. Data collected through the implementation of formative evaluation will be grouped into four parts, namely 1) The first stage evaluation data in the form of the results of an expert test of the contents of travel tourism material; 2) Second stage evaluation data of expert test results on tourism marketing material; 3) Third stage evaluation data of expert test results on book design and 4) The fourth stage of evaluation data in the form of data from one by one trial results, small group trials and field trials, in the form of the results of a review of students and business actors. Descriptive and qualitative analysis techniques are used to process data on the results of reviews from content experts in travel tourism material, tourism marketing experts, learning media experts, and students in individual trials, students and lecturers during field trials. This data technique is done by grouping information from qualitative data in the form of input, responses, criticisms, and suggestions for improvements contained in the questionnaire and the results of the interview. The results of this data analysis are then used to revise tourism business teaching material products. Descriptive and quantitative statistical analysis will be used to analyze quantitative data on assessment responses made by students during field trials on teaching materials that are tested.

\section{Results and Discussion}

The draft of MPDW teaching materials based on production that have been prepared at the time of data collection and Forum Group Discussion will be formative tested with the following stages: 


\section{a. Evaluation one by one with experts}

The results of the validation of tourism material experts are known that the material contained in the MPDW teaching materials based on production is very good, because it has accommodated the basic concepts of tourism and travel needed including history and travel management, tourist motivation, tourism systems, tourism resources, forms of travel, tourism industry, relationships and cooperation, travel route design, travel itinerary preparation, travel cost calculation, product marketing, travel preparation, tourism area development, and ecotourism. The emphasis of the production model is clearly visible from the exercise presented, and the material stages to be carried out.

The results of the validation of marketing experts can be seen that the teaching material developed is generally good. Inputs are given to marketing materials so that links are made with tourism sites and other tourist objects. The exercises should not only focus on group exercises but still provide individual training spaces from designing to marketing to foster courage and interest in entrepreneurship in the tourism business, especially travel to all students.

The development of material based on the validation of the book design expert has been considered very good for the appearance of clearly visible letters, where there is a separation between titles, subtitles and contents, interesting visual quality with layout, font style, distance, and blank fields are good. Input is given in order to better provide clarity of color, especially for words that are keywords and basic concepts.

\section{b. Revision 1}

Based on expert input, the following improvements were made: 1) adding individualized exercises, especially for travel package design training materials and marketing of travel products and 2) marking key words and basic concepts in thicker writing.

\section{c. Evaluation One by One with 3 students}

Formative evaluations for MPDW teaching materials are carried out by the One by One Test by three students in the category of students with medium abilities, above medium and below medium. This sample is representative for the representation of students' abilities. The results are as follows:

Table 1. Test Results for one by one Production-Based MPDW Teaching Materials

\begin{tabular}{llll}
\hline No & Aspect & Average & Category \\
\hline 1. & Display & 3.13 & Good \\
2. & Presentation of Material & 3.16 & Good \\
3. & Benefit & 3.51 & Very Good \\
\hline
\end{tabular}

The data in table 1 shows the assessment of students for the three aspects evaluated can be said to have been good, the whole is above the number 3 which means good even for the benefits of achieving 3.51 which is very good. In the results of this test students suggest that sentences should not be too long, it should be equipped with an explanation for words that are not too familiar with colloquial, and there are still some typos. 


\section{d. Revision 2}

The results of student assessments in the one by one test will be used to revise the draft teaching materials that have been prepared. The second revision is done by improving the way to use shorter and simpler sentences. Foreign words that are not yet familiar with common language are replaced with other words that are in accordance with the rules of the Indonesian language and familial in the academic, and improvements are made for word writing.

\section{e. Small Group Trial with 20 students}

This test is carried out after a revised module draft after obtaining input from one by one tests. These 20 students were given a questionnaire related to the evaluation of the MPDW teaching material draft after revision 2 . The results are as follows:

Table 2. Test Results of Small Groups for Production-Based MPDW Teaching Materials

\begin{tabular}{llll}
\hline No & Aspect & Average & Category \\
\hline 1. & Display & 3.5 & Very Good \\
2. & Presentation of Material & 3.53 & Very Good \\
3. & Benefit & 3.6 & Very Good \\
\hline
\end{tabular}

Data in table 2 shows the assessment of students for the three aspects evaluated can be said to be getting better, where there is an increase in the average of each aspect and all of them in the very good category. The results of this test, students suggest that examples especially for the calculation of travel costs are given in detail so that it is easier for students to understand and apply. For the preparation of the itinerary, it is expected to present an itinerary example in the form of a description and table.

\section{f. $\quad$ Revision 3}

The results of student assessments in the small group test form the basis for revising the three draft MPDW teaching materials that have been prepared. This third revision was made by adding examples of calculations to the material for calculating travel costs. The draft module is also equipped with examples of a complete itinerary in the form of descriptions and tables.

\section{g. Large Group Trial with 38 students}

After the third revision, it means that the draft MPDW teaching materials based on production are ready to be used for field testing. Field test uses one real class, namely students of the Office Administration Education Study Program of 2016 generation from Regular Class which consist of 38 students. In this test students learn by using a draft module that has been arranged by directing students to design a product in the form of a city tour package, calculate travel costs, determine selling prices, create marketing media in the form of pictures and videos, students make publications and marketing through social media. The appraisers of product assessment produced by students are lecturers who are able to see aspects of the theory, but the main appraisal is on market appraisal, namely how the market responds to travel packages prepared by students. Travel package promos uploaded to student social media within 2 weeks of the sale period. After two weeks of sales, students can sell their products with the market's willingness to respond and buy the package. 
In this group trial, students provide input so that the cover of teaching materials is made more attractive by displaying images and designs that can be increasing enthusiasm and interesting to look at.

\section{h. Revision 4}

The results of student assessments in the large group test form the basis for the fourth revision which is the last revision of the draft of teaching material that has been prepared. The fourth revision is done by replacing the cover design of MPDW teaching materials.

\section{i. $\quad$ Field Test}

Different from other tests, a field test for a larger group of researchers is conducted to see how the overall student response to the contents of this production-based teaching material. For this reason, all students currently taking the 110 MPDW course are included in this field test. Students in each class are divided into groups to design products in the form of a broader travel package for the Province of North Sumatra, calculate travel costs, determine the expected level of profit, determine selling prices, create marketing media in the form of images and videos, students make publications and marketing through social media for 2 weeks. Appraisers assessing the products produced by students still involve supporting lecturers to see aspects of their theory. Assessment for the attractiveness and rationality of packages is left to the market, namely how the market responds to travel packages prepared by students. From the travel packages uploaded to students' social media, they have been able to sell products with market will to respond and buy packages. Data packages that are compiled and sold are as follows:

Table 3. Products Produced by Students in the Field Test for Development of Production-Based Teaching Materials

\begin{tabular}{|c|c|c|c|c|c|c|}
\hline No & Class & Travel Name & Package Name & \%Profit & Selling price & Interested \\
\hline 1 & $\mathrm{~A}$ & Mpdw2019cau & $\begin{array}{l}\text { 2D1N Get Paradise love } \\
\text { OurHistory }\end{array}$ & $25 \%$ & Rp 600.000,- & 10 \\
\hline 2 & A & Pesona travel & $\begin{array}{l}\text { 3D2N Medan Parapat } \\
\text { Berastagi }\end{array}$ & $20 \%$ & Rp.600.000,- & 20 \\
\hline 3 & A & $\begin{array}{l}\text { SKYDEe Travel } \\
\text { Medan }\end{array}$ & $\begin{array}{l}\text { 2D2N explore Salah } \\
\text { namo and Pulau Pandang }\end{array}$ & $30 \%$ & Rp 640.000,- & 15 \\
\hline 4 & A & $\begin{array}{l}\text { Vendora Tour } \\
\text { And Travel }\end{array}$ & 2D1N Out & $30 \%$ & Rp700.000,- & 14 \\
\hline 5 & $\mathrm{~B}$ & One Trip Travel & 2D1N Danau Toba trip & $30 \%$ & Rp 630.000,- & 16 \\
\hline 6 & $\mathrm{~B}$ & Sedap Travel & $\begin{array}{l}\text { 2D1N explore Salah } \\
\text { namo and Pulau Pandang }\end{array}$ & $50 \%$ & Rp650.000,- & 22 \\
\hline 7 & $\mathrm{~B}$ & Refan travel & Outbound Tour & $10 \%$ & Rp315.000,- & 19 \\
\hline 8 & $\mathrm{~B}$ & Fan travel Tour & $\begin{array}{l}\text { 2D1N The Most Epic } \\
\text { Travel destination Arum } \\
\text { Jeram Ancol }\end{array}$ & $10 \%$ & Rp 550.000,- & 25 \\
\hline 9 & $\mathrm{C}$ & Santuy Tour & 3D2N Explore 3 District & $20 \%$ & Rp.629.000,- & 23 \\
\hline 10 & $\mathrm{C}$ & $\begin{array}{l}\text { Kedan Travel } \\
\text { Medan }\end{array}$ & $\begin{array}{l}\text { 2D1N Trip to Pandang } \\
\text { and Salahnamo Island }\end{array}$ & $25 \%$ & Rp 600.000,- & 31 \\
\hline 11 & $\mathrm{C}$ & Skuyy Travel & $\begin{array}{l}\text { 3D2N Explore Samosir } \\
\text { Island }\end{array}$ & $20 \%$ & Rp.600.000,- & 15 \\
\hline
\end{tabular}


From table 3 it can be seen that students in the overall field test have been able to design travel packages according to market needs, determine the percentage of profit and the selling price of the packages. The package that was designed was attractive to the market and in a short time a group of students with their travel agency was able to get guests for the package being sold.

\section{j. $\quad$ Teaching Material Model Developed}

The final result of this research is a prototype of a production-based MPDW Teaching Material that will be implemented in the student learning activities in the Office Administration Education Study Program.

\section{Conclusion}

a. The Production-based MPDW teaching materials developed can attract students to enter the travel business this can be seen from the ability of students to open travel agents in groups.

b. The Production-based MPDW Teaching Materials developed can be used to facilitate students to learn to design travel tour packages, be able to set product sales prices, be able to market products and are expected to be able to become tour leaders and tour guides for packages that have been sold.

c. The MPDW Teaching Materials developed are comprehensive teaching materials and easy to use, consisting of 14 chapters including: 1) the basic concept of tourism; 2)history and travel management; 3) tourist motivation; 4) tourism system; 5) tourism resources; 6) travel forms; 7) the tourism industry; 8) relationships and cooperation; 9) travel route design; 10) preparation of the itinerary and calculation of travel costs; 11) product marketing: 12) travel preparations; 13) tourism area development, and 14) ecotourism.

d. To facilitate students in the Office Administration Education Study Program to master the competency of the MPDW subjects, it is recommended to continue the travel business activities that have begun to be pioneered so that their entrepreneurial competencies can still be developed.

e. To be able to maximize in the use of production-based MPDW teaching materials that have been designed, it is better for lecturers who can understand the basic concepts of developing a production-based learning model and its syntax

\section{References}

[1] Gunawan, Bernadinus Ignasius dan Adikampara, I Made. Kesempatan Kerja Bagi Masyarakat Dengan Adanya Bali Safari dan Taman Laut di Desa Serongga Kabupaten Gianyar. Jurnal Destinasi Pariwisata. (2018).

[2] Maba, Wayan. Kurikulum Sarjana Berbasis KKNI Mengubah Mindset Pengajaran Menjadi Pembelajaran. Jurnal Bakti Saraswati. (2016).

[3] Mitasari, Lilis dan Rusdarti. Model Pembelajaran Production Based Learning Training Pada Pembelajaran Prakarya dan Kewirausahaan. Economic Education Analysis Journal. (2018). 
[4] Arsanti, Mulan. Pengembangan Bahan Ajar Mata Kuliah Penulisan Kreatif Bermuatan Nilai Pendidikan Karakter Religius Bagi Mahasiswa Prodi PBSI, FKIP UNISSULA. Jurnal Kredo. (2018).

[5] Prabawa, Dewa Gede Agus Putra. Pengembangan Bahan Ajar Multimedia Berbasis Proyek Untuk Meningkatkan Hasil Belajar Siswa SMK. Jurnal Pendidikan dan Pegajaran. (2013).

[6] Mutmainnah, Sri. Penerapan model pembelajaran kooperatif tipe think pair share (TPS) untuk meningkatkan aktivitas dan hasil perkuliahan mahasiswa jurusan pendidikan ekonomi FE Unimed Medan 2011-2012. Laporan Penelitian. (2012).

[7] Rofiah, E., Siti, A.N., Ekawati, E.Y. Penyusunan Instrumen Tes Kemampuan Berpikir Tingkat Tinggi Fisika pada Siswa SMP. Jurnal Ilmu Pendidikan. (2013).

[8] Sastrika, Ida Ayu Kade, et.al. Pengaruh Model Pembelajaran Berbasis Proyek Terhadap Pemahaman Konsep Kimia dan Keterampilan Berpikir Kritis. E-jurnal Program Pascasarjana Universitas Pendidikan Ganesha Program Studi IPA. (2013). 